\title{
Hydrothermal Interaction of
} Crushed Topopah Spring Tuff and J-13 Water at 90, 150 , and $250^{\circ} \mathrm{C}$ Using Dickson-Type, Gold-Bag Rocking Autoclaves

Kevin G. Knauss, William J. Beiriger, and

Dennis W. Peifer

May 1985 
UCRL -53630

DE86 014752

\section{Hydrothermal Interaction of Crushed Topopah Spring Tuff and J-13 Water at 90, 150 , and $250^{\circ} \mathrm{C}$ Using Dickson-Type, Gold-Bag Rocking Autoclaves}

Kevin G. Knauss, William J. Beiriger, and

Dennis W. Peifer

Manuscript date: May 1985 


\section{Contents}

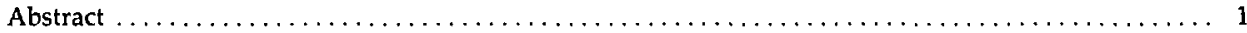

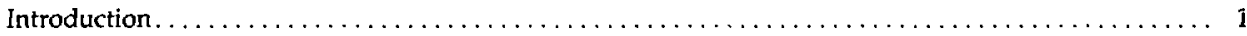

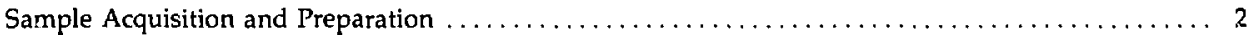

Characterization of Starting Materials $\ldots \ldots \ldots \ldots \ldots \ldots \ldots \ldots \ldots \ldots \ldots \ldots \ldots \ldots \ldots \ldots \ldots \ldots, \ldots \ldots$

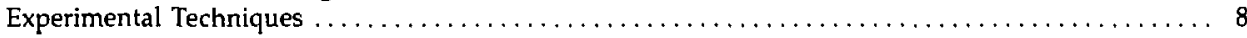

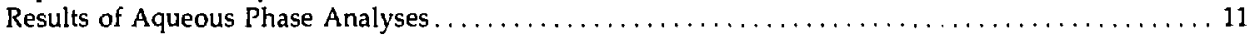

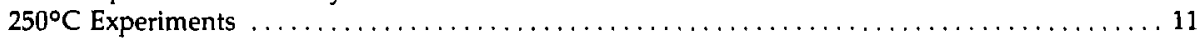

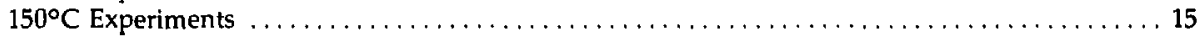

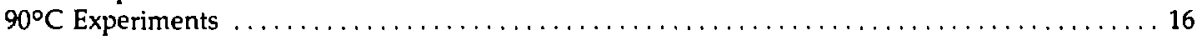

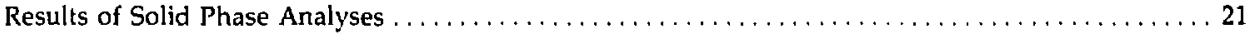

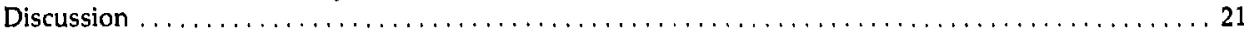

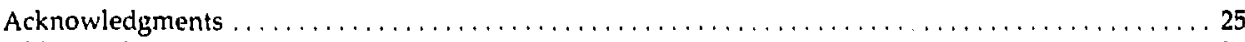

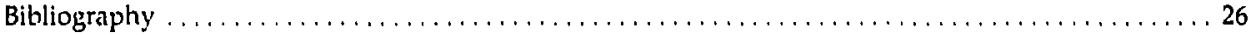


The Tpt used in the experiments run with drillcore material was taken from the interval from 1232.2 to $1232.9 \mathrm{ft}$ in hole USW G-1. This sample is from the zone identified as the potential repository horizon (Tyler, 1982). The sample taken was an intact piece of core that was cut and split so as to provide material for pretest characterization, crushing, and preparation of solid core wafers. For these experiments the tuff was crushed to $-100+200$ mesh size using a flat-plate grinder with high-purity alumina plates. This size range was selected to prevent the gold filter inside the reaction cell from plugging (see the following dis- cussion of experimental apparatus). Note that these samples were also dry-sieved so they would be comparable to the previously prepared outcrop material. Ultrafine material may be present, adhering to the crushed mineral grains. The potential effects on the aqueous chemistry of the reacting fluid are discussed later. The drillcore samples did not need any pretreatment to remove evaporite minerals. Few, if any, of these minerals are observed in drillcore [as contrasted with the outcrop samples (Oversby, 1985)], and the voluminous amounts of water used in the drilling process should have removed them if they were present.

\section{Characterization of Starting Materials}

The reacting fluid in these experiments was $\mathrm{J}-13$ well water. The average of many analyses of this water used in Waste Package experiments is contained in Table 1 (Delany, 1985). An analysis of the J-13 water actually used was made at the start of each experiment. This value is represented as Day 0 in all fluid composition data tables and plots.

Previous characterization of the outcrop Tpt (Knauss, 1984) resulted in a preliminary assignment of relative stratigraphic position within the Tpt section. The Tpt FR outcrop was said to be equivalent to the middle densely welded interval between the two major lithophysal zones. An av-

Table 1. Average composition of J-13 water.

\begin{tabular}{lc}
\hline \multicolumn{1}{c}{ Species } & Concentration \\
\hline $\mathrm{SiO}_{2}$ & 57.8 \\
$\mathrm{pH}$ & 7.6 \\
$\mathrm{HCO}_{3}{ }^{-}$ & 125.3 \\
$\mathrm{~F}^{-}$ & 2.2 \\
$\mathrm{Cl}^{-}$ & 6.9 \\
$\mathrm{NO}_{3}{ }^{-}$ & 9.6 \\
$\mathrm{SO}_{4}{ }^{-}$ & 18.7 \\
$\mathrm{Al}^{+3}$ & 0.012 \\
$\mathrm{~B}^{-\mathrm{OHH}_{3}}$ & 0.128 \\
$\mathrm{Fe}^{+2}$ & 0.006 \\
$\mathrm{C}^{+2}$ & 12.5 \\
$\mathrm{Mg}^{+2}$ & 1.92 \\
$\mathrm{~K}^{+}$ & 5.11 \\
$\mathrm{Na}^{+}$ & 43.9 \\
$\mathrm{Li}^{+}$ & 0.042 \\
$\mathrm{Ch}^{+}$ & $-0.18 \%$ \\
\hline
\end{tabular}

erage of several argon gas adsorption Brunauer Emmett Teeler (BET) surface area measurements showed the crushed outcrop tuff to have a surface area of $1.15 \pm 0.29 \mathrm{~m}^{2} / \mathrm{g}$. A mercury porosimetry analysis of intart Tpt FR (a polished wafer) showed the rock to contain an average pore diameter of $0.031 \mu \mathrm{m}$ and a porosity of $6.51 \%$.

Detailed petrographic analysis of thin sections prepared from Tpt FR outcrop samples has allowed relative stratigraphic position to be more precisely assigned (Byers, 1984). Seven criteria are used to correlate the Tpt FR outcrop with the middle nonlithophysal zone (substantiating the preliminary assignment above) and, more specifirally, probably the lower part of this zone:

1. Feldspar phenocryst ratio,

2. Presence of rounded quartz phenocrysts,

3. Low granophyric content ( $2 \%)$,

4. Low abundance of cristobalite-filled vesicles or amygdules,

5. Cristobalite, as opposed to tridymite, in vesicles,

6. Little or no cryptocrystalline groundmass,

7. Devitrification textures and flattening ratios of relict shards and pumice.

In hole USW G-1 this would correspond to approximately an 800 -ft depth. At this depth the Tpt bears a close mineralogical and geochemical resemblance to the potential repository horizon, which extends from $997-1285 \mathrm{ft}$ below surface. A comparison of the whole-rock geochemistry, petrography, and individual phase geochemistry presented in Knauss (1984) for the Tpt FR outcrop material, as well as similar data for the drillcore material from USW G-1 at $1232.2 \mathrm{ft}$ depth [to be presented below and in the core wafer report (Knauss et al., 1985a)] will bear this out. 
The drillcore sample used to prepare the crushed tuff from USW G-1 1232.2 was characterized, like the outcrop sample, by petrographic examination, XRD, neutron activation analysis (NAA), mercury porosimetry, gas adsorption BET surface area analysis, and SEM/EMP analysis using both wavelength dispersive spectrometry (WDS) and energy dispersive spectrometry (EDS) techniques. Results of this characterization of the drillcore tuff (excluding the SEM/EMP analyses of thin section and polished core wafer) are presented in this report. The characterization of USW G-1 1232.2 derived from SEM/EMP analysis is presented in the core wafer report (Knauss et al., 1985a).

The petrography of the G-1 1232.2 sample was very similar to that of the Tpt FR sample. A thin section of the G-1 1232.2 sample showed the rock to be a densely welded, devitrified tuff. Examples of axiolitic, granophyric and spherulitic devitrification textures were displayed in the originally glassy matrix and pumice, although the largest portion of the matrix consisted of cryptocrystalline groundmass. The mineral assemblage was identical to the Tpt FR sample (phenocrysts of plagioclase, alkali feldspar, quartz, biotite, magnetite, ilmenite and accessory zircon and apatite), although the relative proportions were different. The G-1 1232.2 sample contained a somewhat higher plagioclase/alkali feldspar ratio than the outcrop sample, and lithic fragments were slightly more abundant than phenocrysts. The G-1 1232.2 sample contained less voids than the outcrop sample. The more pronounced draping of relict shards over pumice and phenocrysts suggested that the G-1 1232.2 sample was more densely welded than the Tpt FR sample.

More detailed descriptions and quantitative analysis of the petrography $0:$ nearby samples at 1191- and 1240-ft depths in hole USW G-1 may be found in Bish et al. (1981) and Warren et al. (1984). Based on point counting of 500 points, Warren et al. (1984) found the nearest thin section (at $1240 \mathrm{ft}$ ) to contain $3.2 \%$ lithic fragments, $2.6 \%$ felsic phenocrysts ( $82 \%$ plagioclase), mafic phenocrysts of biotite (2.80 ppm) and iron-titanium oxides $(460 \mathrm{ppm})$, and trace accessory minerals zircon (17 ppm) and apatite (8 ppm). Based on quantitative XRD analysis, Bish et al. (1981) estimate the 1240 -ft sample to contain $2-5 \%$ montmorillonite, $10-20 \%$ quartz, $20-30 \%$ cristobalite, and $30-50 \%$ alkali feldspar.

Because the drillcore sample was crushed and sieved to a specific size fraction $(-100+200$ mesh) rather than simply crushed to pass one sieve size ( -60 mesh), it was necessary to determine if there was any fractionation of the phenocrysts or lithic fragments based on their size distribution. This was accomplished by characterizing both a whole rock sample and the sieved material by XRD and NAA analysis. The XRD spectra are shown in Figs. 1 and 2 (peak d-spacing and intensity are given in Tables 2 and 3) for the whole rock and sieved sample, respectively. The spectra

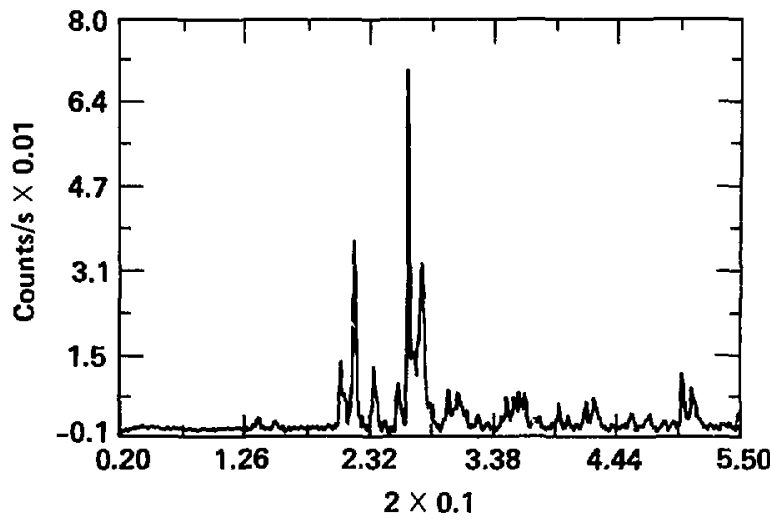

Figure 1. X-ray diffraction spectra for USW G-1 whole rock. 


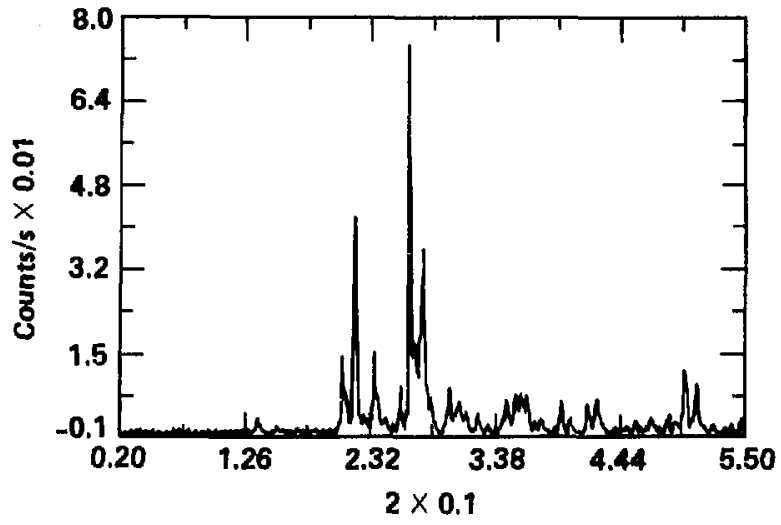

Figure 2. X-ray diffraction spectra for USW G-1 $-100+200$ mesh.

are identical, indicating that no size fractionation of the phenocrysts or lithic fragments occurred as a result of excluding the size fraction less than 200 mesh $(74 \mu \mathrm{m})$. Similarly, Table 4 shows the results of NAA analysis of whole rock for the outcrop sample (Tpt FR) and the drillcore sample (G-1 1232.2) plus the sieved drillcore sample. These data suggest that the whole-rock composition of the outcrop and drillcore samples is very similar. Secondly, the bulk chemistry of the whole rock and sieved drillcore material is very similar. This indicates that the $-100+200$ mesh material is a good representation of the whole rock. A more detailed description of the analytical tech- niques used in this characterization process is given in Knauss (1984).

An average of several argon gas adsorption BET surface area measuremerts showed the crushed drillcore tuff to liave a surface area of $2.67 \pm 0.01 \mathrm{~m}^{2} / \mathrm{g}$. Since the drillcore sample was crushed and sieved to a finer size fraction than the outcrop material, the specific surface area is correspondingly larger. A mercury porosimetry analysis of intact G-1 1232.2 (a polished wafer) showed the rock to contain an average pore diameter of $0.025 \mu \mathrm{m}$ and a porosity of $6.54 \%$. The rock from both outcrop and drillcore is very similar in porosity and average pore size. 
Table 2. X-ray diffraction peaks for USW G-1 1232-ft whole rock.

\begin{tabular}{|c|c|c|c|c|}
\hline $\mathbf{N}$ & 2theta & Dspace & Height & Area \\
\hline 1 & 13.68 & 6.469 & 23 & 8.3 \\
\hline 2 & 15.20 & 5.824 & 14 & 3.4 \\
\hline 3 & 19.04 & 4.658 & 5 & 1.0 \\
\hline 4 & 20.88 & 4.251 & 132 & 34.6 \\
\hline 5 & 21.96 & 4.044 & 365 & 106.9 \\
\hline 6 & 22.64 & 3.924 & 24 & 5.9 \\
\hline 7 & 23.60 & 3.767 & 125 & 45.5 \\
\hline 8 & 24.64 & 3.610 & 36 & 4.6 \\
\hline 9 & 25.80 & 3,450 & 84 & 21,9 \\
\hline 10 & 26.68 & 3.338 & 702 & 141,2 \\
\hline 11 & 27.76 & 3,211 & 317 & 132.8 \\
\hline 12 & 28.48 & 3.131 & 50 & 8.8 \\
\hline 13 & 29.88 & 2,988 & 81 & 24,8 \\
\hline 14 & 30.80 & 2.901 & 61 & 20.5 \\
\hline 15 & 31.40 & 2.846 & 37 & 12.1 \\
\hline 16 & 32.44 & 2.757 & 25 & 5.9 \\
\hline 17 & 33.29 & 2.689 & 9 & 1.7 \\
\hline 18 & 34.88 & 2.570 & 65 & 20.5 \\
\hline 19 & 35.64 & 2.517 & 62 & 20.2 \\
\hline 20 & 36.12 & 2.485 & 70 & 23.1 \\
\hline 21 & 36.56 & 2.456 & 69 & 17.5 \\
\hline 22 & 37.80 & 2.378 & 26 & 9.2 \\
\hline 23 & 38.83 & 2.317 & 10 & 2.0 \\
\hline 24 & 39.48 & 2.281 & 56 & 16.11 \\
\hline 25 & 40.27 & 2.237 & 27 & $" .4$ \\
\hline 26 & 41.76 & 2.161 & 49 & 12.4 \\
\hline 27 & $\$ 2.48$ & 2.126 & 63 & 15.3 \\
\hline 28 & 44.04 & 2.054 & 10 & 1.7 \\
\hline 29 & 45.24 & 2.003 & 15 & 3.1 \\
\hline 30 & 45.80 & 1.979 & 27 & 4.7 \\
\hline 31 & 47.32 & 1.919 & 28 & 9.2 \\
\hline 32 & 49.40 & 1.843 & 17 & 5.6 \\
\hline 33 & 50.16 & 1.817 & 113 & 35.4 \\
\hline 34 & 50.96 & 1.791 & 85 & 33.4 \\
\hline 35 & 52.48 & 1.742 & 9 & 2.0 \\
\hline 36 & 53.44 & 1.713 & 12 & 2.0 \\
\hline 37 & 54.12 & 1.693 & 15 & 3.6 \\
\hline
\end{tabular}


Table 3. X-ray diffraction peaks for USW G-1 1232-ft $-100+200$ mesh.

\begin{tabular}{|c|c|c|c|c|}
\hline $\mathbf{N}$ & 2theta & Dspace & Height & Area \\
\hline 1 & 3.60 & 24.554 & 5 & 1.0 \\
\hline 2 & 13.64 & 6.486 & 29 & 10.2 \\
\hline 3 & 15.24 & 5.808 & 12 & 3.8 \\
\hline 4 & 20.88 & 4.251 & 148 & 25.9 \\
\hline 5 & 21.96 & 4.044 & 417 & 128.6 \\
\hline 6 & 22.60 & 3.931 & 35 & 5.9 \\
\hline 7 & 23.60 & 3.767 & 156 & 43.4 \\
\hline 8 & 24.60 & 3.616 & 29 & 11.2 \\
\hline 9 & 25.20 & 3.531 & 15 & 4.1 \\
\hline 10 & 25.85 & 3.444 & 88 & 24.9 \\
\hline 11 & 26.64 & 3.343 & 746 & 183.6 \\
\hline 12 & 27.72 & 3.216 & 355 & 108.6 \\
\hline 13 & 28.49 & 3.131 & 63 & 16.2 \\
\hline 14 & 29.96 & 2.980 & 86 & 27.8 \\
\hline 15 & 30.88 & 2.893 & 59 & 14.0 \\
\hline 16 & 31.44 & 2.843 & 40 & 10.0 \\
\hline 17 & 32.49 & 2.754 & 32 & 9.5 \\
\hline 18 & 33.24 & 2.693 & 11 & 2.7 \\
\hline 19 & 34.52 & 2.596 & 30 & 7.9 \\
\hline 20 & 34.84 & 2.573 & 67 & 20.5 \\
\hline 21 & 35.64 & 2.517 & 74 & 17.2 \\
\hline 22 & 36.08 & 2.487 & 73 & 19.0 \\
\hline 23 & 36.52 & 2.458 & 68 & 23.4 \\
\hline 24 & 37.24 & 2.412 & 23 & 3.7 \\
\hline 25 & 37.76 & 2.381 & 26 & 8.1 \\
\hline 26 & 38.96 & 2.310 & 11 & 3.5 \\
\hline 27 & 39.44 & 2.283 & 60 & 16.5 \\
\hline 28 & 40.28 & 2.237 & 26 & 6.7 \\
\hline 29 & 41.72 & 2.163 & 51 & 14.6 \\
\hline 30 & 42.48 & 2.126 & 59 & 18.4 \\
\hline 32 & 43.91 & 2.060 & 7 & 1.7 \\
\hline 32 & 45.75 & 1.981 & 20 & 4.2 \\
\hline 33 & 47.08 & 1.929 & 28 & 6.6 \\
\hline 34 & 48.48 & 1.876 & 19 & 7.5 \\
\hline 35 & 48.60 & 1.872 & 18 & 4.7 \\
\hline 36 & 49.20 & 1.850 & 22 & 4.9 \\
\hline 37 & 50.12 & 1.819 & 118 & 43.0 \\
\hline 38 & 50.96 & 1.790 & 89 & 35.3 \\
\hline 39 & 53.44 & 1.713 & 10 & 2.4 \\
\hline
\end{tabular}


Table 4. Nisutron activation analyees of Tpt FR (WR) vs G-1 1232.2 (WR) vs G-1 1232.2 $(-100+200)$.

\begin{tabular}{|c|c|c|c|}
\hline Eleneal & Tpt FR (WR) & G-1 1232.2 (WR) & G-1 1232.2 \\
\hline $\mathbf{N} \mathbf{a}^{\mathbf{a}}$ & 2.81 & 2.35 & 2.44 \\
\hline $\mathbf{K}$ & 3.93 & 3.78 & 3.99 \\
\hline Fe & 0.62 & 0.62 & 0.66 \\
\hline$S c^{b}$ & 2.26 & 2.24 & 2.28 \\
\hline $\mathrm{Co}$ & 0.16 & 0.20 & L.16 \\
\hline $\mathbf{Z n}$ & 42.9 & 39.9 & 42.4 \\
\hline At & 4,61 & 4.12 & 4.85 \\
\hline $\mathbf{R b}$ & 87.8 & 200.0 & 182.5 \\
\hline $\mathbf{Z r}$ & 53.6 & 135.2 & 111.0 \\
\hline $\mathbf{S b}$ & 0.33 & 1.57 & 0.32 \\
\hline Co & 3.82 & 3.88 & 3.89 \\
\hline Ba & $\mathbf{5 2 . 6}$ & 68.5 & 79.9 \\
\hline La & 35.6 & 36.3 & 35.2 \\
\hline $\mathrm{Ce}$ & 65.5 & 72.2 & 74.3 \\
\hline Sm & 5.90 & 5.50 & 5.63 \\
\hline Eu & 0.27 & 0.26 & 0.26 \\
\hline$T b$ & 0.77 & 0.67 & 0.70 \\
\hline Yb & 3.01 & 2.89 & 3.02 \\
\hline Lu & 0.52 & 0.53 & 0.54 \\
\hline Hf & 4.99 & 4.77 & 4.68 \\
\hline $\mathbf{T} \mathbf{3}$ & 1.33 & 1.33 & 1.36 \\
\hline Th & 22.1 & 22.0 & 22.6 \\
\hline $\mathbf{U}$ & 4.27 & 4.60 & 4.70 \\
\hline
\end{tabular}

\section{Experimental Techniques}

All experiments are done in Lickson-type, gold-bag rocking autoclaves (see Fig. 3), which contain an inner, flexible gold bag (containing the reacting solids and fluid) that collapses as sample fluid is withdrawn. Additional distilled water is injected into the surrounding autoclave to maintain constant pressure (Seyfreid et al., 1979). The volume of the gold bag is approximately $230 \mathrm{ml}$, and thus many samples may be taken from the same solution without quenching the run. The gold bag is sealed by a titanium collar and titanium head containing a gold filter, which prevents solids from being removed along with the fluid samples withdrawn from the cell. The fluid sample passes through a gold capillary tube contained within a stainless exit tube, past a titanium needle valve assembly, from where it is bled through a Teflon nipple into a plastic syringe (see Fig. 4). In this way the solution is only exposed to gold and titanium during the experiment plus Teflon and plastic upon sampling.
The entire pressure vessel is contained within a large furnace heated by an electrical resistance heater. The whole assembly (pressure vessel plus furnace) is constantly rocked through $180^{\circ} \mathrm{C}$ at a rate of six cycles per minute on a large rack holding two fumaces. The autoclave is pressurized with distilled water and the pressure is monitored with gauges mounted on each furnace. The furnace temperature is controlled using digital proportionating temperature controllers. The internal vessel temperature is measured using chromelalumel thermocouples and digital thermometers accurate to $\pm 1^{\circ} \mathrm{C}$. The sheathed thermocouples are calibrated against a platinum resistance thermometer tertiary standard, which itself is calibrated against a National Bureau of Standards (NBS) secondary standard. Thermocouple calibrations are conducted in silicon oil in a well-stirred constant temperature bath. End-to-end system verification is made by substituting an accurately known voltage from a low impedance source in 


\section{Figure 3. Cut-away schematic of Dickeon-type gold-bag rocking autoclave.}

place of the thermocouple and adjusting meter output, if required.

This type of system has many advantages over the more common cold-seal type vessels used for rock/water interaction experiments. In cold-seal reaction vessels numerous problems can occur because minerals and solutions remain in contact during the quench. Reactions between solution and primary solid phases on quench can significantly change the relative concentration of cations from those present in solution at high pressure and temperature (Walther and Orville, 1983). In the Dickson-type vessels samples of fluid may be taken at run conditions of temperature and pressure without having to quench the vessel and dismantle the run. Samples derived from the same starting fluid may be obtained at various times throughout the course of one experiment. It is also possible to inject solutions of known composition back into the gold bag and thus perturb the system from a known direction (i.e., from supersaturation or undersaturation) without disrupting the experimental setup. The reaction cell and sampling gear are extremely nonreactive, and temperature and pressure regions of some considerable interest (up to $400^{\circ} \mathrm{C}$ and $2 \mathrm{kbar}$ ) are attainable.

Run setup begins by adding a preweighed amount of crushed tuff to the gold bag followed by an appropriate amount of J-13 water (allowing 


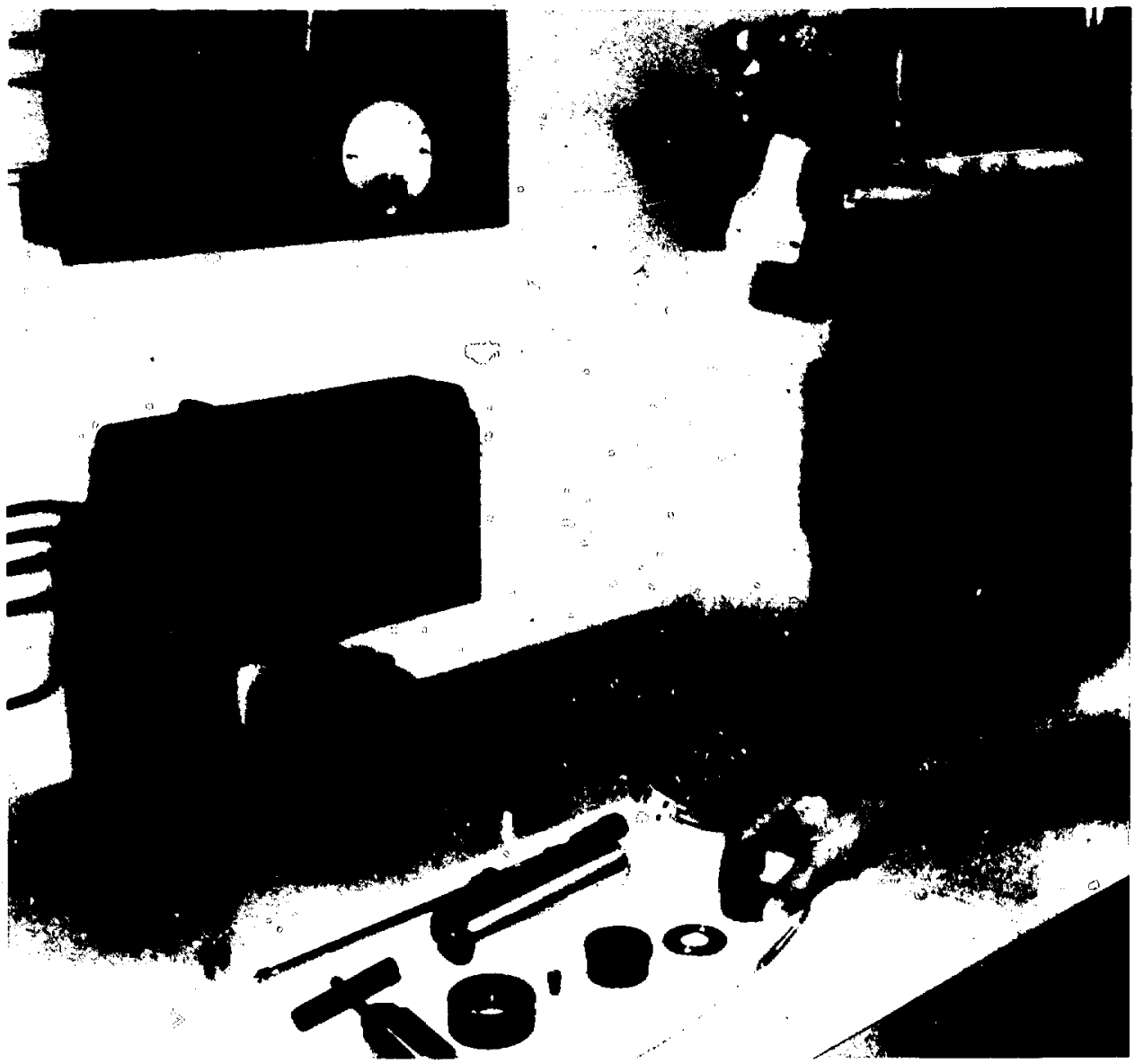

Figure 4. Disassembled gold bag + titanium reaction cell and assembled pressure vessel.

for volume expansion at run temperature). After assembling the gold bag and pressure vessel, the air void at the top of the gold bag is gently squeezed out by slightly pressuring the vessel before pressurizing the vessel to near run conditions. The heatir.e jacket is then switched on, and as temperature rises distilled water is bled from the pressure vessel to maintain run pressure conditions. Run conditions for these experiments (90 to $250^{\circ} \mathrm{C}$ and 50 to 100 bar) are reached within several hours, and the continuous rocking of vessel and furnace is begun. The short-term runs reported on here last from 66 to 82 days during which time the rocking motion is halted only dur- ing sampling. Long-term runs, to be reported on later (Knauss et al., 1985b), have lasted up to 303 days.

Samples are drawn from the gold bag through the titanium valve and injected into a preweighed plastic rispcsable syringe. Approxin?ately $1 \mathrm{ml}$ of fluid is first drawn off and discarded to bleed any stagnant solution from the gold capillary tube. Aliquots of fluid are drawn slowly to avoid flashing and are used for the analyses described in more detail below. Pressure is maintained with a Sprague pump during the sampling procedure. For the shortterm experiments an effort is made to sample in the progression 1, 2, 4, 8, 16, 32, 48, and 64 days after 
starting. At the conclusion of each run the furnace power is switched off and the pressure vessel is disassembled as soon as is practical (approxirately 10 to 15 hours, depending on run temperature). analyses:

The fluid samples are used for a variety of

1. An unfiltered sample is used for an immediate $\mathrm{pH}$ measurement using a glass electrode and digital meter.

2. A filtered $(0.1 \mu \mathrm{m})$ and acidified (Ultrox nitric acid) sample is run both full-strength and diluted for cation analysis via inductively coupled plasma, emission spectrometry (ICP.ES).

3. A filtered, acidified sàmple is run fullstrength for potassium via atomic absorption (AA).

4. A filtered sample is used for anion analysis via ion chromatography (IC).

5. For these experiments using crushed tuff, the carbonate alkalinity was measured on unfiltered samples using IC. Although efforts were made to prevent gas exchange (storage in glass vials and analysis the same day in most cases), some analyses showed evidence of volatile gain or loss (pH or alkalinity change). The alkalinity data presented in this report have been edited to remove analyses that are known to be suspect, based on gross changes in solution $\mathrm{pH}$ between the time of sampling and the time of alkalinity analysis or abnormally high measured alkalinity values. In addition, attempts to model the results using EQ3/6 (Delany, 1985) show a systematic negative charge balance in many experiments even for the analyses not edited using these criteria. It was found that charge balancing on alkalinity resulted in reasonable and consistent values for each experiment, again arguing for a problem in the $\mathrm{IC}$ alkalinity data. In subsequent experiments (Knauss et al, 1985a and b), the total $\mathrm{CO}^{2}$ is determined by total inorganic carbon analysis with infrared (IR) detection of the evolved $\mathrm{CO}^{2}$ gas.

The solid run products are air-dried in a desiccator and analyzed by XRD. The experimental apparatus and conditions of analysis are identical to those used in the pretest characterization. No attempt is made to use SEM/EMl" techniques for post-test analysis of the crushed-tuff experinentrun products, since analogous experiments are run using solid polished wafers of tuff, whicli are much more amenable to such analyses. Details concerning the results of such post.test solid phase analyses on analogous experiments using solid wafers of tuff are provided in Knauss and Beiriger (1984b) and Knauss et al. (1984. 1985a, and b).

\section{Results of Aqueous Phase Analyses}

\section{$250^{\circ} \mathrm{C}$ Experiments}

Two short-term experiments were run at $250^{\circ} \mathrm{C}$ using $\mathrm{J}-13$ water as the reacting fluid. One was run at 50 bars of pressure and used crushed drillcore tuff (DB11), and the other was run at 100 bars an' ied crushed outcrop tuff (DB5). The results of -FS cation analyses are summarized in Table 5, wrile the IC anion analyses and $\mathrm{pH}$ are given in Table 6 . These data are plotted vs reaction time for DB11 in Figs. 5a (silicon and sodium) and $5 \mathrm{~b}$ (aluminum, calcium, potassium, magnesium, and $\mathrm{pH}$ ) and Figs. 6a and $6 \mathrm{~b}$ for DB5.

The outcrop tuff was pretreated to remove the evaporite minerals known to be present in the rock. By crushing, sieving, and treating the samples in the same way as those used in previous experiments (Oversby, 1984a and b, 1985), we hoped to be able to discern those experimental results attributable simply to differences in the autoclaves used !Teflon-lined Parr bombs and Dickson-type gold-bag rocking autoclaves). The dala from the crushed outcrop tuff experiment (DB5) readily show that the pretreatment procedure did not remove all the evaporite minerals. When we compare the outcrop experiment data for the cations (sodium, potassium, and, to a lesser extent, silicon and calcium cations) as well as the anions $\left(\mathrm{SO}_{4}, \mathrm{Cl}\right.$, and, to a less obvious extent, $\mathrm{NO}_{3}$ ) with those for the drillcore experiment, they show clearly that the outcrop tuff still contained these salts. The $\mathrm{pH}$ was also slightly higher in the outcrop tuff experiment.

There are two probable causes for these observations. First, the rock/water ratio during the cleaning step used here was almost five times greater than in the Parr bomb experiments (Oversby, 1984a) and it is possible that the solution had saturated with respect to some of the evaporite minerals. In this situation they would be 
Table 5. Inductively compled plasma, emiacion spectrometry" cation analyese for $250^{\circ} \mathrm{C}$ experinow. Amounts in parts per million.

\begin{tabular}{|c|c|c|c|c|c|c|}
\hline Smapie & A] & si & Ca & $\mathbf{K}$ & $\mathrm{M}_{8}$ & $\mathbf{N}$ \\
\hline \multicolumn{7}{|l|}{ Drillcore } \\
\hline Di⿻11-0 & 0.036 & 29.1 & 13.2 & 4.72 & 1.68 & 39.9 \\
\hline DD11-1 & 3.01 & 365 & 2.65 & 5.74 & 0.384 & $\mathbf{4 0 . 7}$ \\
\hline De11-2 & 3.07 & 342 & 2.06 & 5.29 & 0.197 & 39.7 \\
\hline DS11-4 & 2.00 & 342 & 1.61 & 5.22 & 0.127 & 37.6 \\
\hline DE11-8 & 2.9 & 350 & 0.78 & 5.29 & 0.015 & 37.2 \\
\hline D211-16 & 3,03 & 348 & 0.71 & 4.43 & 0.192 & 34.7 \\
\hline D.311-32 & 3.43 & 34 & 0.32 & 3.77 & 0.010 & 38,3 \\
\hline DN11-50 & 3.35 & 353 & 0.27 & 4.04 & 0.012 & 36,9 \\
\hline DA11-46 & 3.33 & 399 & 0.21 & 3,17 & 0.015 & 59.1 \\
\hline \multicolumn{7}{|l|}{ Outcrep } \\
\hline$\overline{\text { DIS-O }}$ & 0.040 & 29.2 & 13,1 & 4.73 & 1.50 & 41.2 \\
\hline Das-9 & $\mathbf{4 . 4}$ & 394 & 2.4 & 10,3 & 0.243 & 64.4 \\
\hline DIS-16 & 2.92 & 374 & 1.38 & 9.15 & 4.022 & 66.9 \\
\hline DD5-30 & 2.77 & 374 & 0.54 & 9.75 & 0.013 & 71.9 \\
\hline Des-49 & 2.69 & 348 & 0.48 & 10.3 & 0.023 & 73.8 \\
\hline De5-64 & 2.61 & 391 & 0.66 & 10.4 & 0.009 & 74.4 \\
\hline
\end{tabular}

- Direct reading unit.

Table 6. Inductively coupled anion analyses and pHI for $250^{\circ} \mathrm{C}$ experiments.

\begin{tabular}{|c|c|c|c|c|c|c|}
\hline Sample & $\mathbf{p H}$ & $\underset{\text { (mmol/l) }}{\mathrm{HCO}_{3}}$ & $\begin{array}{c}\text { F } \\
\text { (ppm) }\end{array}$ & $\underset{\text { (ppm) }}{\mathrm{Cl}}$ & $\begin{array}{c}\mathrm{NO}_{3} \\
\text { (ppm) }\end{array}$ & $\begin{array}{c}\mathrm{SO}_{4} \\
\text { (Ppm) }\end{array}$ \\
\hline \multicolumn{7}{|l|}{ Drillcore } \\
\hline DB11-0 & 7.79 & 1.90 & 2.2 & ij.5 & 8.5 & 18.1 \\
\hline DE11-1 & 6.28 & 1.19 & 2.8 & 7.3 & 8.9 & 18.6 \\
\hline D811-2 & 6.18 & 1.18 & 2.9 & 7.3 & 9.0 & 18.5 \\
\hline DD11-4 & 6.11 & 1.09 & 3.1 & 7.2 & 9.5 & 18.6 \\
\hline DB11-8 & 5.95 & 1.05 & 3.4 & 7.2 & 9.5 & 18.6 \\
\hline Ds11-16 & 5.87 & 1.13 & 3.9 & 8.5 & 10.5 & 18.3 \\
\hline Ds11-32 & 5.90 & $0.74^{n}$ & $4.0^{4}$ & $7.6^{4}$ & $11.5^{4}$ & $13.3^{2}$ \\
\hline DE11-50 & 5.04 & $0.95^{4}$ & $4.3^{4}$ & $8.0^{n}$ & $16.8^{4}$ & 18.9 \\
\hline DB11-66 & 6.01 & $1.13^{\prime}$ & $4.4^{\prime \prime}$ & $7.0^{\circ}$ & 7.94 & 17.9 \\
\hline \multicolumn{7}{|l|}{ Outcrop } \\
\hline $\overrightarrow{\mathrm{DE5}-0}$ & 7.81 & 2.30 & 2.3 & 6.6 & 9.0 & 18.1 \\
\hline DB5-9 & 6.72 & $3.07^{b}$ & 3.4 & 8.1 & 10.7 & 21.0 \\
\hline D)5-16 & 6.46 & 2.13 & 2.2 & 7.9 & 9.4 & 20.9 \\
\hline De5-30 & 6.74 & 2.31 & 3.7 & 8.0 & 10.0 & 19.5 \\
\hline Des-49 & 7.10 & $2.24^{6}$ & 4.3 & 8.9 & 9.1 & 20.0 \\
\hline Dis-GA & 6.87 & 2.36 & 44 & 7.9 & 9.5 & 19.7 \\
\hline
\end{tabular}

\footnotetext{
New IC amelyat = encpect data.

- Preblema with IC HCO, mesouremeat; valuet ranged from 173 to $187 \mathrm{ppm}$ resulting in large negative charge balance. See text for detalls.
} 


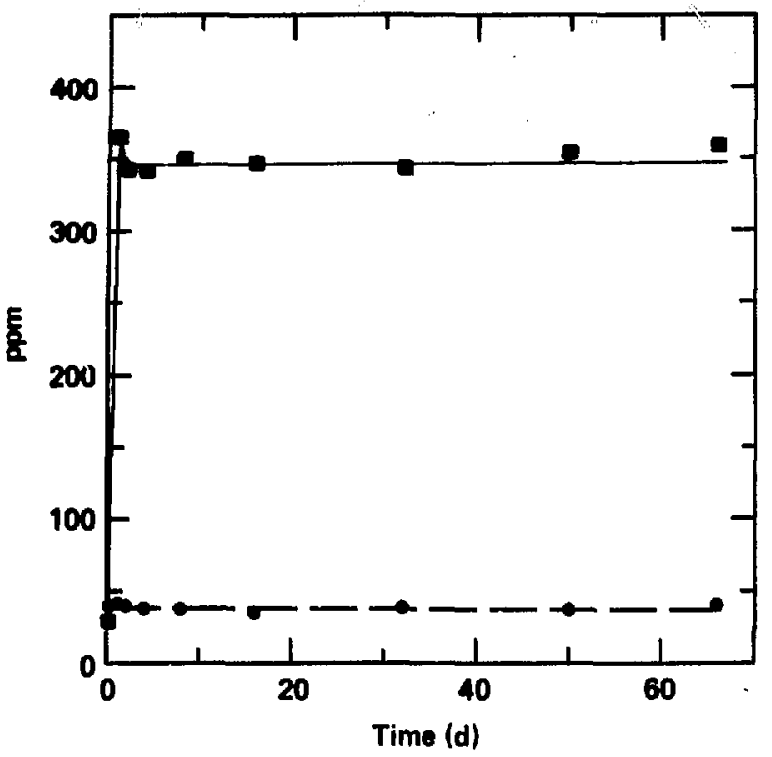

Figure 5a. Diseolved silicon and sodium in the $250^{\circ} \mathrm{C}$ experiment run with drillcore tuff.

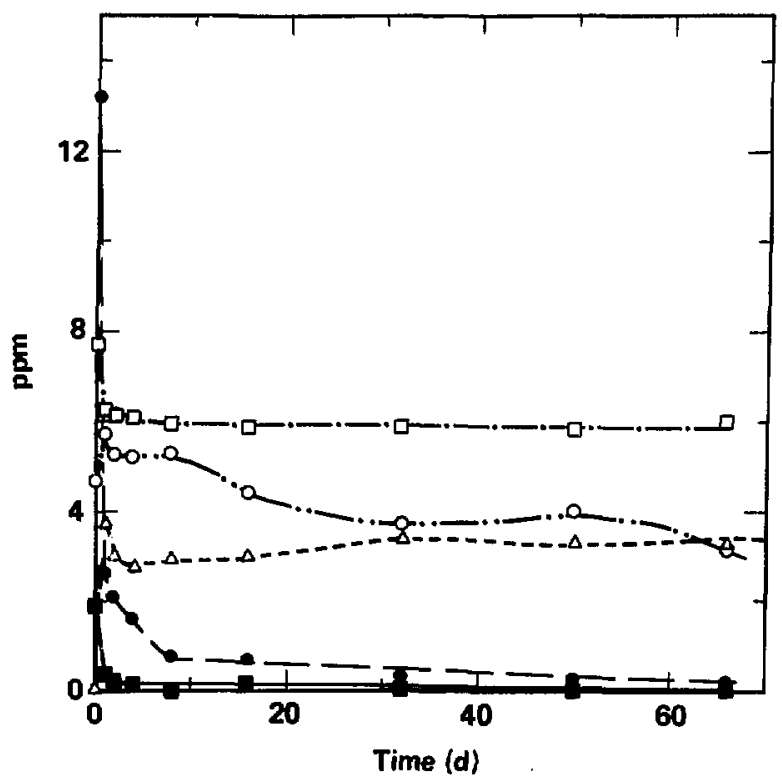

Figure 5b. Diwolved aluminum, calcium, potassium, magnevium, and solution pH (at $25^{\circ} \mathrm{C}$ ) in the $250^{\circ} \mathrm{C}$ experiment run with drillcore tuff. 


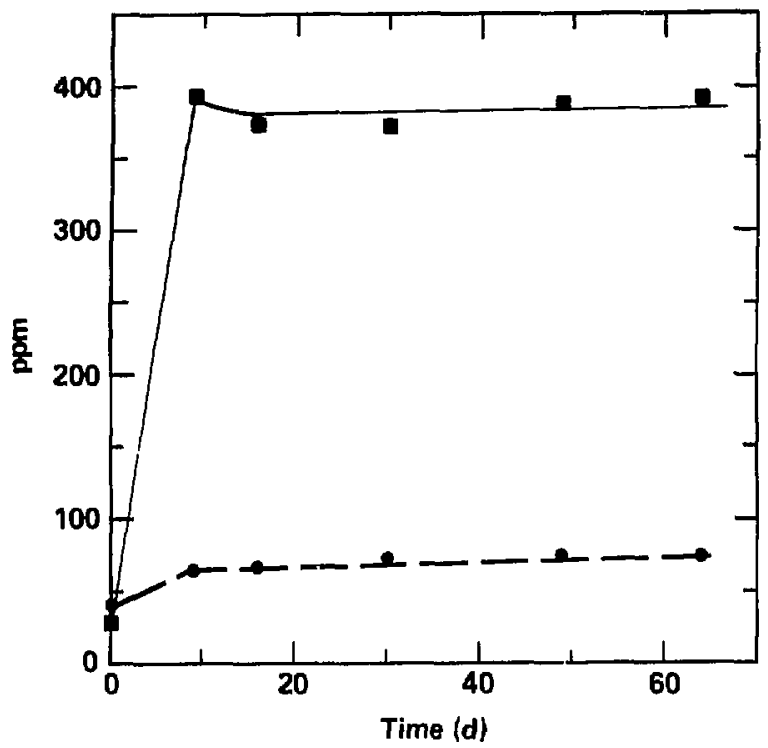

Figure 6a. Dissolved silicon and sodium in the $250^{\circ} \mathrm{C}$ experiment run with outcrop tuff.

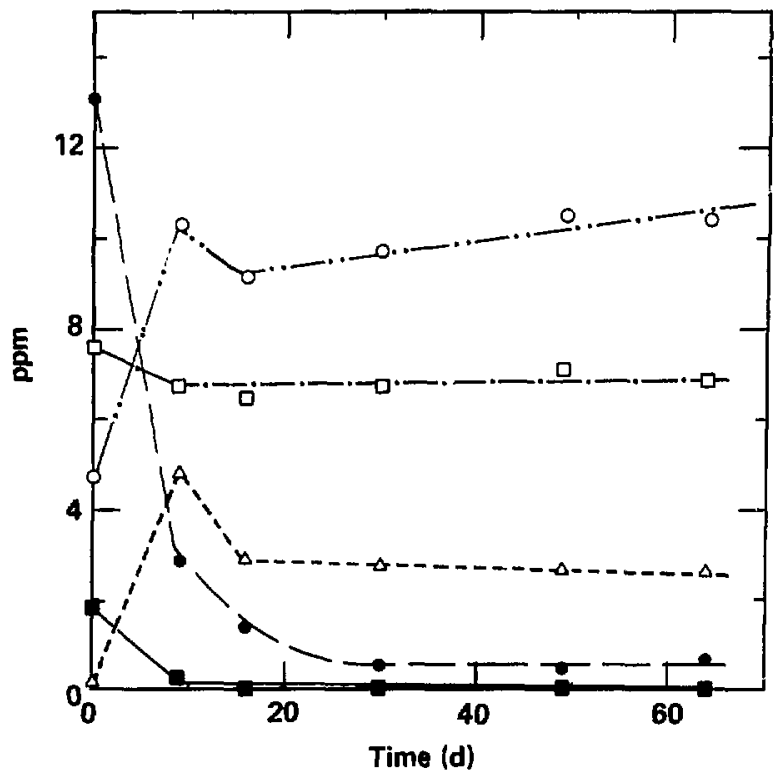

Figure 6b. Dissolved aluminum, calcium, potassium, magnesium, and solution pH (at $25^{\circ} \mathrm{C}$ ) in the $250^{\circ} \mathrm{C}$ experiment run with outcrop tuff. 
incompletely removed from the outcrop rock during the pretreatment. Second, the cleaning step was done in Teflon-lined Parr bombs at $150^{\circ} \mathrm{C}$, a practical mpper limit to which the Teflon liners could be taken. The experiment, however, was run in the Dickson bombs at $250^{\circ} \mathrm{C}$. It is possible that some of the evaporite mineral phases were not sufficiently soluble at $150^{\circ} \mathrm{C}$ to be completely removed, and they were available to the fluid at the higher temperature of the experiment.

After accounting for the differences between the outcrop and drillcore crushed tuff experiments tue to the presence of evaporite minerals, there are trends in the concentrations of elements with time that are consistent between the two Dickson bomb experiments run at this temperature. The silicon concentration very quickly comes to an essentially steady-state value. Sodium changes very little during the experiment. The $\mathrm{pH}$ drops quickly and remains constant. The calcium and even more quickly the magnesium are removed from solution. Both potassium and aluminum show an initial rise in concentration followed by a decrease, which slows with time of reaction. With the exception of a very slight increase in the solubility of carbonates with: pressure, the pressure difference between the two experiments should not preclude comparing aqueous concentrations of elements.

\section{$150^{\circ} \mathrm{C}$ Experiments}

Two short-term experiments were also run at $150^{\circ} \mathrm{C}$ with $\mathrm{J}-13$ water using crushed drillcore tuff (DB10) at 50 bars and crushed outcrop tuff (DE4) at 100 bars pressure. The results of ICP-ES cation analyses are summarized in Table 7 , while the IC anion analyses and $\mathrm{pH}$ are given in Table 8 . These data are plotted vs reaction time in Figs. 7 a (silicon and sodium) and $7 \mathrm{~b}$ (aluminuin, calcium, potassium, magnesium, and $\mathrm{pH}$ ) for DB10 and Figs. 8. and $8 \mathrm{~b}$ for DB4.

Some differences in the aqueous concentrations of elements between experiments run with drillcore tuff and outcrop tuff that are attributed to the presence of evaporite minerals in the outcrop samples are accentuated at $150^{\circ} \mathrm{C}$. The prime example is potassium, which rises to $18 \mathrm{ppm}$ in the outcrop tuff experiment. Aluminum is removed more slowly from solution as the reaction progresses in the outcrop tuff experiment. The large difference found in sodium concentration between drillcore and outcrop experiments at $250^{\circ} \mathrm{C}$ is not seen at $150^{\circ} \mathrm{C}$. For the other species (silicon, $\mathrm{pH}$, calcium, and magnesium) the differences are slight between the drillcore and outcrop tuff experiments. The general trends with time at $150^{\circ} \mathrm{C}$ are similar to those already described for the

Table 7. Inductively coupled plasma, emission spectrometry ${ }^{2}$ cation analyses for $150^{\circ} \mathrm{C}$ experiments. Amounts in parts per million.

\begin{tabular}{llccccc}
\hline Sample & Al & Si & Ca & K & M8 & Na \\
\hline Drillcore & & & & & & \\
\hline DB10-0 & 0.054 & 29.1 & 13.1 & 4.77 & 1.91 & 41.5 \\
DB10-1 & 3.56 & 79.5 & 9.87 & 9.86 & 0.677 & 47.1 \\
DB10-2 & 1.47 & 96 & 8.19 & 9.20 & 0.177 & $\$ 7.5$ \\
DB10-4 & 0.802 & 109 & 7.52 & 7.9 & 0.064 & 4.0 \\
DB10-8 & 0.622 & 125 & 7.02 & 7.73 & 0.067 & 48.4 \\
DB10-16 & 0.438 & 130 & 6.77 & 6.79 & 0.032 & 49.5 \\
DB10-32 & 0.507 & 133 & 5.95 & 5.91 & 0.057 & 54.2 \\
DB10-50 & 0.490 & 142 & 5.86 & 6.55 & 0.032 & 56.2 \\
DB10-66 & 1.64 & 148 & 6.46 & 5.58 & 0.315 & 58.5 \\
Outcrop & & & & & & \\
\hline DB4-0 & 0.040 & 29.2 & 13.1 & 4.73 & 1.90 & 41.2 \\
DB4-6 & 3.13 & 92 & 6.38 & 15.9 & 2.72 & 48.1 \\
DB4-16 & 1.99 & 112 & 6.41 & 17.3 & 0.126 & 50.7 \\
DB4-33 & 1.54 & 127 & 6.77 & 17.7 & 0.463 & 51.1 \\
DB4-48 & 1.37 & 134 & 4.80 & 19.4 & 0.012 & 55.6 \\
DB4-63 & 1.13 & 139 & 5.85 & 19.1 & 0.014 & 55.9 \\
DB4-82 & 0.951 & 149 & 5.50 & 17.8 & 0.029 & 56.4 \\
\hline
\end{tabular}

"Direct reading unit. 
Table 8. Inductively coupled anion analyses and $\mathrm{pH}$ for $150^{\circ} \mathrm{C}$ experiments.

\begin{tabular}{|c|c|c|c|c|c|c|}
\hline Sample & $\mathbf{p H}$ & $\begin{array}{c}\mathrm{HOC}_{3} \\
\text { (mmol/l) }\end{array}$ & $\underset{\text { (ppm) }}{F}$ & $\underset{\text { (ppm) }}{\mathrm{Cl}}$ & $\begin{array}{c}\mathrm{NO}_{3} \\
\text { (ppm) }\end{array}$ & $\begin{array}{c}\mathrm{SO}_{4} \\
\text { (ppm) }\end{array}$ \\
\hline \multicolumn{7}{|l|}{ Drillcore } \\
\hline DB10-0 & 7.86 & 2.41 & 2.3 & 6.5 & 9.0 & 17.6 \\
\hline DB10-1 & 7.07 & 1.92 & 2.6 & 7.6 & 9.8 & 18.6 \\
\hline DB10-2 & 6.98 & 1.77 & 2.6 & 7,6 & 9.7 & 18.4 \\
\hline DB10-4 & 6.97 & 1.74 & 2.5 & 7.1 & 9.5 & 18.5 \\
\hline DB10-8 & 6.85 & 1.69 & 2.6 & 7.4 & 10.4 & 18.2 \\
\hline DB10-16 & 6.87 & 1.73 & 2.6 & 7.4 & 9.7 & 18.3 \\
\hline DB10-32 & 6.91 & $1,64^{4}$ & $2.4^{a}$ & $7.1^{\star 4}$ & $16,6^{4}$ & 18.6 \\
\hline DB10-50 & 6.98 & $1.67^{a}$ & $3.1^{4}$ & $7.5^{4}$ & $16.7^{n}$ & $18.8^{\bullet}$ \\
\hline DB 10.66 & 6.97 & $1.00^{2}$ & $2.4^{4}$ & $7.4^{4}$ & $9.5^{\mathbf{2}}$ & $18,5^{4}$ \\
\hline \multicolumn{7}{|l|}{ Outcrop } \\
\hline DE4-0 & 7.81 & 2.30 & 2.3 & 6.6 & 9.0 & 18.1 \\
\hline DB4-6 & 7.05 & 2.16 & 2.4 & 8.0 & 12.5 & 20.2 \\
\hline DB4-16 & 7.14 & 2.20 & 2.5 & 8.0 & 11.8 & 20.6 \\
\hline DB4-33 & 7.20 & $2.63^{b}$ & 2.4 & 7.9 & 11.1 & 20.0 \\
\hline DB4-48 & 7,20 & 2.22 & 2.4 & 7.5 & 10.1 & 19.1 \\
\hline DB4-63 & 7.36 & 2.12 & 2.4 & 7.6 & 10.2 & 19.3 \\
\hline DB4-82 & 7.45 & $2.40^{b}$ & 2.5 & 7.8 & 10.5 & 19.7 \\
\hline
\end{tabular}

New analyst = suspect data.

b Problems with IC HCO, measurement; values ranged from 146 to 160 resulting in large negative charge balance. See text for details.

$250^{\circ} \mathrm{C}$ experiments. Hypotheses to account for the trends as a function of temperature will be offered in the discussion to follow.

Experiments have been run previously using crushed outcrop and drillcore tuff at this temperature in the Teflon-lined Parr bombs (Oversby, 1984a and b, 1985). The differences between results, using the two types of vessels (Parr hombs vs Dickson-type gold-bag rocking autoclaves) have been enumerated for solid wafers of outcrop tuff (Knauss and Beiriger, 1984a). Primarily, these include degassing volatiles through the Teflon during the course of the experiment and quenching effects during the act of sampling the Parr bombs. A comparison of the results reported here for crushed drillcore tuff (DB10) and crushed outcrop tuff (DB4) with similar experiments done in Parr bombs (Oversby, 1985; Oversby, 1984a, respectively) clearly shows the effect of degassing volatiles in the Parr bomb experiments (changes in $\mathrm{pH}$ and alkalinity). The major species in solution, however, show no evidence for quench effects upon sampling.

\section{$90^{\circ} \mathrm{C}$ Experiment}

A short-tr.rm experiment was run using only crushed drilicore tuff reacted with J-13 water at $90^{\circ} \mathrm{C}$ and 50 bars of pressure (DB15). The results of ICP-ES cation analyses are summarized in Table 9, while the IC anion analyses and $\mathrm{pH}$ are given in Table 10. These data are plotted vs reaction time in Figs. 9a (silicon and sodium) and 9b (aluminum, calcium, potassium, magnesium, and pH) for DB10.

Since only the drillcore tuff was run in this experiment, there should be no effects from evaporite minerals. The trends in solution composition are similar to those seen in the $150^{\circ} \mathrm{C}$ experiment (DB10), only less pronounced. The relative increase in silicon is much smaller, and the sodium concentration is somewhat more variable. The decreases in calcium, magnesium, and $\mathrm{pH}$ are all less pronounced at this temperature. The potassium initially increases to almost the same concentration as at $150^{\circ} \mathrm{C}$, but then decreases less (to $8 \mathrm{ppm})$ than at the higher temperature $(6 \mathrm{ppm})$. At this temperature the initial pulse in aluminum may be smaller (although it is hard to be certain, since the day 2 analyses are unavailable), but the concentration is maintained at a higher level than at $150^{\circ} \mathrm{C}$. The anion content of the $\mathrm{J}-13$ water is changed very little (if at all) by reaction with the rock, and shows no evidence of the presence of evaporite minerals. 


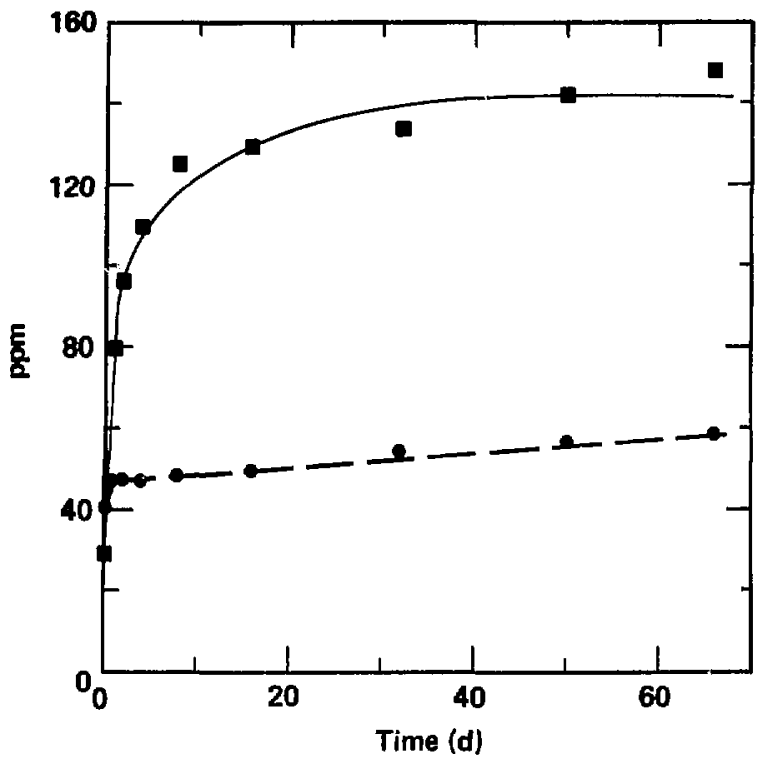

Figure 7a. Dissolved silicon and sodium in the $1500^{\circ} \mathrm{C}$ experiment run with drillcore tuff.

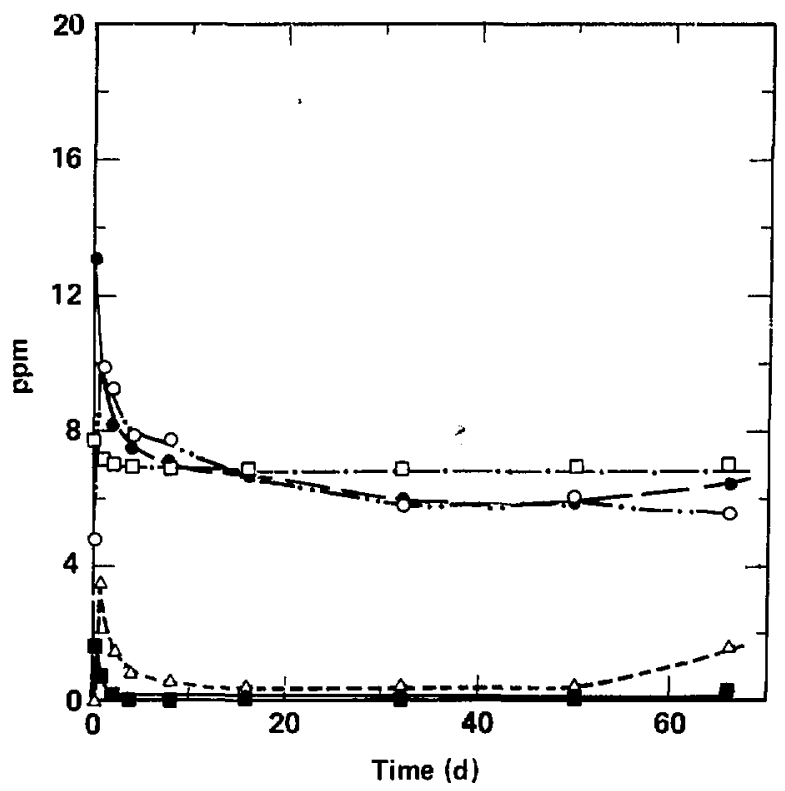

Figure $7 \mathrm{~b}$. Dissolved aluminum, calcium, potassium, magnesium, and solution $\mathrm{pH}\left(25^{\circ} \mathrm{C}\right.$ ) in the $150^{\circ} \mathrm{C}$ experiment run with drillcore tuff. 


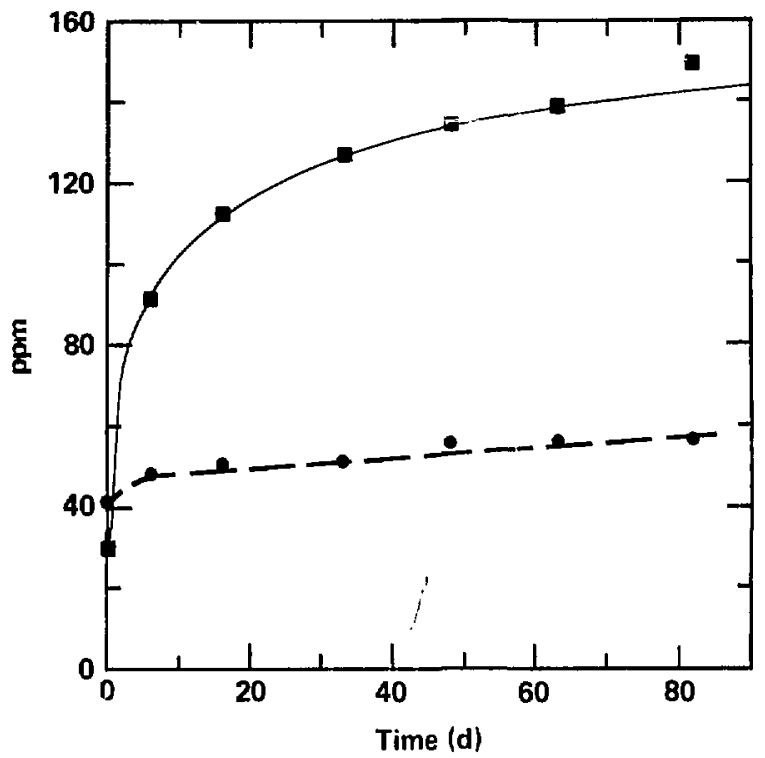

Figure 8a. Dissolved silicon and sodium in the $150^{\circ} \mathrm{C}$ experiment run with outcrop tuff.

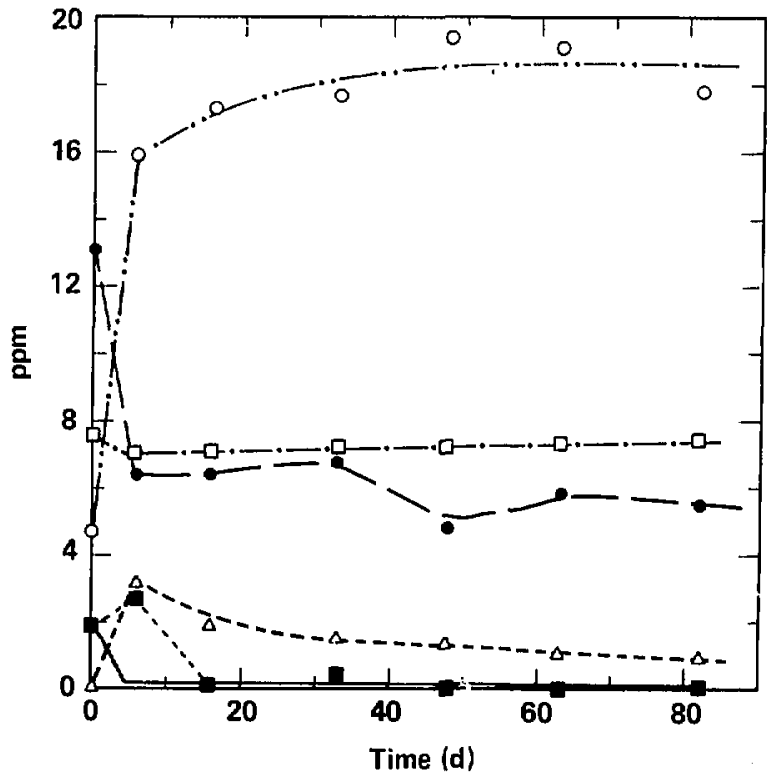

Figure 8b. Dissolved aluminum, calcium, potassium, magnesium, and solution $\mathrm{pH}\left(a t 25^{\circ} \mathrm{C}\right.$ ) in the $150^{\circ} \mathrm{C}$ experiment run with outcrop tuff. 
Table 9. Inductively coupled piasma, emission epectrometry cation analyses for $90^{\circ} \mathrm{C}$ experiment (in parts per million).

\begin{tabular}{lcccccc}
\hline $\begin{array}{c}\text { Drillcore } \\
\text { sample }\end{array}$ & Al & Si & Ca & K & Mg & Na \\
\hline DB15-0 & 0.016 & 30.5 & 14.5 & 5.0 & 2.0 & 49.0 \\
DB15-2 & 6 & 43.0 & 13.5 & 7.5 & 0.90 & 52.0 \\
DB15-4 & 2.0 & 47.0 & 13.5 & 10.4 & 1.00 & 55.0 \\
DB15-8 & 6 & 42.5 & 13.5 & 8.5 & 1.15 & 57.5 \\
DB15-16 & 6 & 49.5 & 13.0 & 8.5 & 1.10 & 54.5 \\
DB15-32 & 1.30 & 52.5 & 12.5 & 8.0 & 1.10 & 52.0 \\
DB15-46 & 1.03 & 52.5 & 12.7 & 9.0 & 1.15 & 57.5 \\
DB15-63 & 0.803 & 51.0 & 11.3 & 8.0 & 1.10 & 59.5 \\
DB15-71 & 0.999 & 53.0 & 11.5 & 7.5 & 1.10 & 55.0 \\
\hline
\end{tabular}

- Sequential unit.

b Undiluted aliquot consumed before aluminum alialyois. Not accurately determined in diluted ample, hence unreported by analyst.

Table 10. Inductively coupled anion analyses and $\mathrm{pH}$ for $90^{\circ} \mathrm{C}$ experiment.

\begin{tabular}{lcccccc}
\hline $\begin{array}{l}\text { Drillcore } \\
\text { sample }\end{array}$ & $\mathrm{pH}$ & $\begin{array}{c}\mathrm{HCO}_{3} \\
(\mathrm{mmol} /)^{4}\end{array}$ & $\begin{array}{c}\mathrm{F} \\
(\mathrm{ppm})\end{array}$ & $\begin{array}{c}\mathrm{Cl} \\
(\mathrm{ppm})\end{array}$ & $\begin{array}{c}\mathrm{NO}_{3} \\
(\mathbf{p p m})\end{array}$ & $\begin{array}{c}\mathrm{SO}_{4} \\
(\mathbf{p p m})\end{array}$ \\
\hline DB15-0 & 7.78 & 2.98 & 2.2 & 7.0 & 8.2 & 18.5 \\
DB15-2 & 7.38 & 2.65 & 2.5 & 7.5 & 9.1 & 18.8 \\
DB15-4 & 7.42 & 3.17 & 2.4 & 7.3 & 9.2 & 19.0 \\
DB15-8 & 7.35 & 2.78 & 2.4 & 7.2 & 9.1 & 18.8 \\
DB15-16 & 7.38 & 2.90 & 2.5 & 7.1 & 9.1 & 18.4 \\
DB15-32 & 7.32 & 2.78 & 2.8 & 8.0 & 9.6 & 18.9 \\
DB15-46 & 7.32 & 2.64 & 2.4 & 7.2 & 9.2 & 18.5 \\
DB15-63 & 7.30 & 2.35 & 2.3 & 7.1 & 8.7 & 18.1 \\
DB15-71 & 7.27 & 2.93 & 2.3 & 7.2 & 9.0 & 18.3 \\
\hline
\end{tabular}

a Problem vith IC $\mathrm{HCO}_{3}$ measurement; values ranged from 143 to $193 \mathrm{ppm}$ resulting in large negative charge balance. See text for details. 


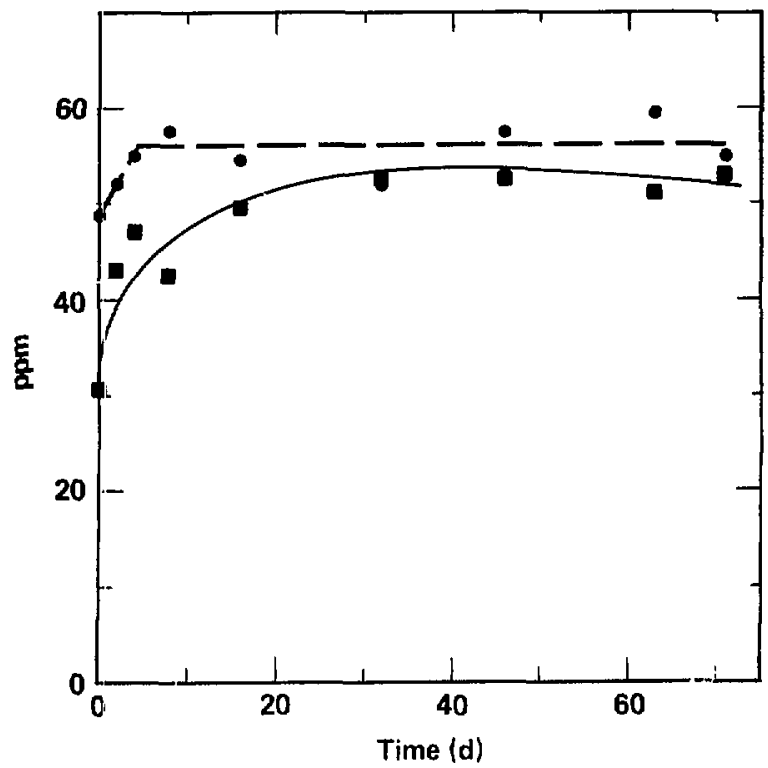

Figure 9a. Dissolved silicon and sodium in the $90^{\circ} \mathrm{C}$ experiment run with drillonre tuff.

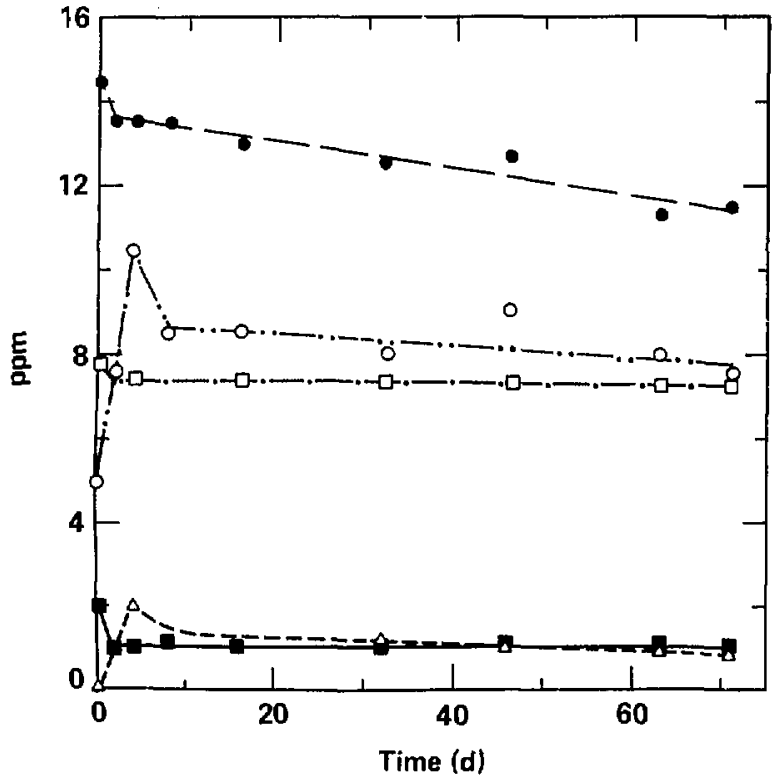

Figure 9b. Dissolved aluminum, calcium, potassium, magnesium, and solution $\mathrm{pH}\left(\right.$ at $25^{\circ} \mathrm{C}$ ) in the $90^{\circ} \mathrm{C}$ experiment run with drillcore tuff. 


\section{Results of Solid Phase Analyses}

In these experiments (performed with crushed tuff), the only analytical tool used for identification of run products and post-test characterization of solid phases is XRD. The resulting $X R D$ spectra are all very similar and in fact virtually indistinguishable from the XRD spectra of the unreacted crushed tuff presented earlier. Although the detection limit for XRD is not especially good ( \pm several $\%$ ), we can say that there were no large changes in overall composition of the starting materials in any of the experiments, nor were large amounts of secondary minerals produced.

The XRD system used to generate the spectra previously shown was recently "quantified" (Pawloski, 1983). The results of analyses using this system for the starting materials and corresponding reacted solids following each experiment are presented in Table 11. The dominant source of dissolved silica in solution in these reac- tions is cristobalite. The dissolution rate of cristobalite is considerably greater than that of alkali feldspar or quartz (the other major silica sources) at all three temperatures. Thus, we would expect a greater change (net relative loss) in cristobalite content than in either alkali feldspar or quartz. A change of $2 \%$ in composition of the sample is just barely at the detection limit for the XRD system for those minerals with the highest sensitivity, and is well below the detection limit for many other minerals. The data in. Table 11 do show that there may be a net loss in cristobalite relative to alkali feldspar and quartz in the reacted solids from experiment DB5 $\left(250^{\circ} \mathrm{C}\right.$, outcrop) compared with the unreacted starting outcrop crushed tuff. In all the other experiments the amounts of the minerals present before and after reaction are indistinguishable within the measurement uncertainty.

\section{Discussion}

Under expected repository conditions at Yucca Mountisit the infiltration rate is slow and the flux of water is low. We anticipate that water should be in an approximately steady-state condition with the rock and adjust its composition to remain so during the thermal exclirsions caused by the disposal of radioactive waste. To determine the composition of water available to interact with the waste package and waste form we must determine the steady-state composition of this water at various temperatures. The use of crushed material

Table 11. "Quantitative" XRD analyses of preand post-test solids.

\begin{tabular}{|c|c|c|c|}
\hline Sample & $\begin{array}{l}\text { Quartz } \\
\text { (\%) }\end{array}$ & $\begin{array}{c}\text { Cristobalite } \\
(\%)\end{array}$ & $\begin{array}{c}\text { Feldepar } \\
\text { (\%) }\end{array}$ \\
\hline Tpt FR $(0)^{a}$ & 42 & 29 & 29 \\
\hline G-1 $1232.2(d)^{b}$ & 43 & 31 & 26 \\
\hline $\operatorname{DB} 15\left(\mathrm{~d}, 90^{\circ} \mathrm{C}\right)$ & 42 & 32 & 27 \\
\hline DB10 $\left(d, 150^{\circ} \mathrm{C}\right)$ & $\$ 1$ & 31 & 29 \\
\hline DB4 $\left(0,150^{\circ} \mathrm{C}\right)$ & 43 & 29 & 28 \\
\hline DB11 (d,250 $\left.0^{\circ} \mathrm{C}\right)$ & 46 & 28 & 26 \\
\hline DB5 & 49 & 22 & 29 \\
\hline
\end{tabular}

- (o) = outcrop.

b $(d)=$ drillcrop. to increase $S A / V$ ratios and hence accelerate the rate of reaction progress in rock/water interaction experiments is a common experimental practice. The experiments reported on here attempt to use this approach (crushed tuff reacted with appropriate water at various temperatures) to determine the approximate composition of water expected to be present in the package environment.

In the highest temperature experiments $\left(250^{\circ} \mathrm{C}\right)$, the solution compositions measured as a function of time-using the drillcore experiment (DB11) as an example-do suggest that, at least over the short-term ( 60 to 90 days), several of the species approach a nearly constant concentration (quasi-steady-state). These species include: silicon, sodium, calcium, magnesium, $\mathrm{pH}$, and possibly the anions, including bicarbonate. The species that are clearly not at steady-state are potassium and aluminum. After an initial rapid rise in concentration, both of these elements decrease in proportion, which would be consistent with the precipitation of a potassium-aluminum-silicon zeolite/clay phase. The potassium is still decreasing at the end of the drillcore tuff experiment and appears to be leveling off at a constant value. The drop in calcium and magnesium concentration at the beginning of the experiment coincides with the initial drop in $\mathrm{pH}$ and alkalinity, suggesting 
that these elements are removed as carbonates because of their retrograde solubility. The silicon concentration in the drillcore experiment is constant at approximately $350 \mathrm{ppm}$. This value is very close to the experimentally determined equilibrium solubility of alpha-cristobalite at $345 \mathrm{ppm}$ (Fournier and Rowe, 1962). The increase in silicon concentration observed on the first day may be the effect of the initial rapid dissolution of ultrafine paticles adhering to the surfaces of the crushed tuff grains. This effect of ultrafines is commonly observed in the dissolution of silicate minerals (Holdren and Berner, 1979; Petrovich, 1981) when specific precautions are not taken to mechanically remove them by ultrasonic cleaning. An analogous experiment using a solid core wafer of tuff (Knauss et al, 1985a) has been modeled by EQ3/6 (Delany, 1985), and the reader is referred to this work for a detailed explanation of the assumptions required to model these experiments as well as a description of the agreement between experimental and modeled results.

Based solely on the results of these shortterm $250^{\circ} \mathrm{C}$ experiments, we can predict a steadystate solution composition at this temperature similar to that shown in Table 12. Better estimates of this steady-state water composition could be made by doing long-term experiments at this temperature and by adequately modeling short-term

Table 12. Estimated steady-state water composition based on short-term Dickson-type rocking autoclave experiments using crushed tuff.

\begin{tabular}{lccc}
\hline Species & $\begin{array}{c}90^{\circ} \mathrm{C} \\
(\mathrm{ppm})\end{array}$ & $\begin{array}{c}150^{\circ} \mathrm{C} \\
(\mathrm{ppm})\end{array}$ & $\begin{array}{c}250^{\circ} \mathrm{C} \\
(\mathrm{ppm})\end{array}$ \\
\hline $\mathrm{Si}$ & 52 & 145 & 350 \\
$\mathrm{Na}$ & 55 & 56 & 39 \\
$\mathrm{~K}$ & 7.5 & 5.5 & 3.2 \\
$\mathrm{Al}$ & $0.8^{4}$ & 0.5 & 3.3 \\
$\mathrm{Ca}$ & 11 & 6 & 0.2 \\
$\mathrm{MB}_{\mathrm{B}}$ & 1.1 & $0.03^{2}$ & 0.01 \\
$\mathrm{pH}^{\mathrm{c}}$ & 7.3 & 7.0 & 6.0 \\
$\mathrm{HCO}_{3}{ }^{\mathrm{d}}$ & $\mathrm{d}$ & 107 & 67 \\
$\mathrm{~F}$ & 2.3 & 2.6 & 3.9 \\
$\mathrm{Cl}$ & 7.1 & 7.4 & 8.5 \\
$\mathrm{NO}_{3}$ & 9.0 & 9.7 & 10 \\
$\mathrm{SO}_{4}$ & 18.3 & 18.3 & 18 \\
\hline
\end{tabular}

Excluding laut tample (day 71).

bxcluding last sampie (day 66).

e $25^{\circ} \mathrm{C}$ pH.

Note comments in text concerning alkalinity measurement. experinents using a reaction path geochemical modeling code such as EQ3/6 and then calculating a composition at long reaction time. This would require significant improvement in the zeolite thermodynamic and kinetic data base (Delany, 1985). No long-term hydrothermal experiments at $250^{\circ} \mathrm{C}$ are currently planned using either crushed tuff or solid wafers of tuff.

In the $150^{\circ} \mathrm{C}$ short-term experiments-using the drillcore tuff experiment (DB10) as an example-fewer of the dissolved species appear to be approaching a semi-constant value by the end of the run. Hence, extrapolating results to describe a steady-state water composition becomes tenuous. Only pH (and possibly aluminum, calcium, potassium, and magnesium) and the anions, in. cluding bicarbonate, are clearly unchanging with further reaction time. For aluminum and magnesium, only the last sample (day 66) suggests that a nearly steady-state value has not been reached. The elevated concentrations of aluminum and magnesium are confirmed by cation analyses on two different ICP-ES instruments, which suggests the possibility that particulate material was present in the acidified sample. Both silicon and sodium still appear to be increasing slightly in concentration towards the end of the runi $x$

The trends for each species are very similar to those seen at the higher temperature. For example, calcium and magnesium drop exponentially from solution, and potassium and aluminum show initial pulses followed by removal from solution. The major difference is that the rate at which each trend develops is slower at the lower teinperature. The silicon concentration in solution towards the end of the run (about $140 \mathrm{ppm}$ ) is $14 \%$ higher than the calculated equilibrium solubility of alphacristobalite (122 ppm) determined by Walther and Helgeson (1977). At first we thought this may be yet another effect due to supersaturation from rapid initial dissolution of ultrafines on the surface of crushed tuff, followed by some sluggish precipitation kinetics for alpha-cristobalite. However, results from a recently completed long;-term experiment ( 303 days) in which a solid wafer of Tpt was reacted with $\mathrm{J}-13$ water at $150^{\circ} \mathrm{C}$ yielded a steady-state value for silicon concentration of approximately $140 \mathrm{ppm}$, maintained from day 64 through the end of the run (Knauss et al., 1985b). These wafers were prepared so that no ultrafines were present. In these later core wafer experiments the rate of increase in silicon concentration at the beginning of the experiment was much slower than in the crushed tuff experiment, which agrees with the SEM observation of no fines being 
present and a lower specific surface area, as determined by argon BET analyses.

The DB10 experiment (crushed tuff at $150^{\circ} \mathrm{C}$ ) has been modeled using the EQ3/6 reaction path code and the results are presented in Delany (1985), which also includes results of geochemical modeling of the analogous short-term experiment run with a solid core wafer (Knauss et al., 1985a). Since the diminished particle size accelerates the rate of reaction progress, short-term crushed tuff experiments can be compared with long-term experiments using solid wafers of tuff. This procedure also allows an opportunity to verify the reaction products predicted to form at a certain temperature from two separate EQ3/6 models, i.e., models constructed using different sets of input parameters such as SA/V ratio and reaction time. Modeling of the long-terni solid wafer experiments at $150^{\circ} \mathrm{C}$ is planned.

Based solely on the results of these shortterm $150^{\circ} \mathrm{C}$ crushed tuff experiments, we would predict a steady-state composition of water at this temperature similar to that shown in Table 12. We confirmed this estimated steady-state water composition based on the results of an analogous long-term experiment, which used a solid wafer of tuff (Knauss et al,, 1985b). Although the concentration trends of several dissolved species did not appear to be stabilized at the end of this shortterm crushed tuff experiment, they actually changed very little with increased reaction time during the long-term core water experiment. The largest differences between the short- and long. term experiments were seen for sodium and possibly potassium.

At $90^{\circ} \mathrm{C}$, the only short-term crushed tuff ex. periment used drillcore tuff (DB15); no experiments were made with outcrop tuff. In this experiment only a few of the dissolved species seem to be present in a constant amount by the end of the run. Only the solution $\mathrm{pH}$, magnesium, the anions, and perhaps aluminum do not appear to be changing in concentration with time. The other species are either still changing in some fairly consistent manner (e.g., calcium) or they are slightly erratic in their concentration trends (e.g., potassium or sodium). In spite of this fact, the discernible trends in the solution composition with time are consistent with those seen at both of the higher temperatures. For example, the initial drop in solution $\mathrm{pH}$ is again accompanied by drops in calcium and magnesium; both aluminum and potassium display initial increases followed by removal from solution; and silicon appears to be present in solution in an amount (about $52 \mathrm{ppm}$ ) consistent with the calculated equilibrium solubility of alpha-cristobalite at 49 ppm (Walther and Helgeson, 1977). No attempts have been made to model this short-term experiment using crushed tuff, nor have any long-term experiments been run at $90^{\circ} \mathrm{C}$ using crushed tuff. Rather, the analogous long-term experiment at this temperature will be run using a solid wafer of tuff.

At this temperature the rate and extent of reaction between rock and water are minor, suggesting that any prediction of a steady-state water composition based on this short-term experiment would be equivocal. The estimated steady-state composition of water in contact with Tpt at $90^{\circ} \mathrm{C}$ (given in Table 12) should be regarded as prelimlnary, and should be superseded by those estimates based on long-term experiments at this temperature using solid wafers of tuff (Knauss et al., 1985b).

The results presented in this report for crushed Tpt reacted with J-13 water can be used to describe the chemical differences in solution composition that result from using outcrop material (only partially cleaned of evaporite minerals) instead of drillcore material.

The solution compositions at $250^{\circ} \mathrm{C}$ show that relatively large differences between outcrop and drillcore experiments were seen for potassium, sodium, and the anions (especially chlorine and $\mathrm{SO}_{4}$ ). The outcrop experiment produced much higher increases in the concentrations of these species relative to the initial J-13 water composition than those seen in the drillcore experiment. Possibly slight effects (all in the sense of outcrop concentrations higher than drillcore concentrations) appeared for silicon, $\mathrm{pH}$, sodium, and the maximum alurtinum concentration.

The $150^{\circ} \mathrm{C}$ experiments also showed relatively large differences for potassium and the anions (especially $\mathrm{NO}_{3}$ and $\mathrm{SO}_{4}$ ), but not for sodium between the outcrop and drillcore experiments. Although the potassium increased to ligher concentrations in the $150^{\circ} \mathrm{C}$ experiments than in the $250^{\circ} \mathrm{C}$ experiments, the relative difference (outcrop vs drillcore) was essentially the same at the two temperatures. Minor effects (outcrop higher than drillcore) also appeared in the $\mathrm{pH}$ and aluminum concentrations in the $150^{\circ} \mathrm{C}$ experiments. The comparison of outcrop and drillcore experiments at 150 and $250^{\circ} \mathrm{C}$ reinforces the points made by Oversby (1984a, 1985). Failure to remove evaporite minerals from outcrop material results in measurably higher solution concentrations for potassium (and to a lesser extent sodium and calciuin), chlorine, $\mathrm{NO}_{3}$, and $\mathrm{SO}_{1}$ than 
those produced in similar experiments using tuff acquired from drillcore. If the presence of additional amounts of these species will adversely affect the applicability of results obtained in experiments designed to mimic repository conditions, then caution should be exercised in using outcrop material as a substitute, and steps should be taken to remove the evaporite minerals.

If we consider only the aqueous phase results at all three temperatures, a consistent picture can be developed concerning both the chemical evolution of the solution in contact with the tuff and the reaction products expected to form as a result of the tuff/water interaction. In a very simplified manner we might infer that at each temperature the trends with time in solution composition could be explained by the following sequence of events: The dissolution of the fine-grained devitrification products cristobalite and alkali feldspar contribute species to solution (e.g., silicon, aluminum, potassium, and sodium). The dominant phenocrysts (sanidine and plagioclase) also contribute the same species to solution. Minor amounts of anions are released into solution as their trace mineral sources (biotite, amphibole, and apatite) dissolve. The alkaline earths originally present in the water are removed rapidly owing to their retrograde solubility, resulting in rapid initial decreases in calcium, magnesiurn, $\mathrm{pH}$, and alkalinity. As the concentrations of the elements in solution increase with continued reaction progress, the solubility limits for various mineral phases (e.g., zeolites and clays) are exceeded and they precipitate from solution, sometimes following periods of kinetic inhibition (e.g., potassium and aluminum).

The simulations of the dissolution of Tpt in J-13 water made using the EQ3/6 geochemical modeling code (Delany, 1985) show relativaly good agreement between predicted solution composition and the analyticai results obtained here or in the analogous experiments using solid core wafers. The predicted solution compositions include a detailed description of speciation of dissolved constituents and a determination of the expected minerai assemblage (remaining reacting phases plus run products) based on the relative degree of saturation $(\log Q / K)$ for a large number of minerals. The results conform to the generalizations above. To confirm the mineral assemblage predicted by the modeled rock/water interaction we must know the identity and chemical character of the run products actually produced in these or analogous experiments. As shown in this report, at these low temperatures with the relatively nonreactive (i.e., nonglassy) tuff used, the extent of reaction is such that XRD analysis of the crushed tuff following rock/water interaction is not sensitive enough to perform this function. Identification and chemical characterization of the run products produced at these temperatures $(90,150$, and $250^{\circ} \mathrm{C}$ ) will be based on SEM/EMP analyses of solid wafers of tuff used in analogous experiments (Knauss et al., 1985a and b).

In these short-term experiments, as the fluid becomes supersaturated with a large number of aluminosilicate phases, the initial mineral assemblage is dominated by those minerals with the highest growth rate (Dibble and Tiller, 1981). These minerals are often metastable, although they are known to persist in the natural envlronment for significant periods of time $\left(10^{3} y\right)$. It may not be correct to dismiss as irrelevant the results of a particular hydrothermal run because the run products are not those predicted to exist at equilibrium. In fact, it may be particularly pertinent to consider the nature and composition of these metastable phases. They may be the very phases present in the near-field environment during the time period when total activity is highest because of the contribution of the fission products. They may continue to exist metastably even into the period when total activity is largely determined by the actinides. An understanding of the chemical composition, mineralogy, and thermomechanical and sorptive properties of these metastable phases may be very important.

The fact that the trends in solution composition are consistent at all three temperatures, and that the main effect of temperature appears to be an increase in the rate at which these trends develop with time, might be used to argue that the mechanisms involved in both dissolution of primary phases and precipitation of reaction products are the same at all three temperatures. In tinis case, increasing temperature alone provides a method of accelerating these tuff/water interactions to predict long-term interaction at lower temperatures.

Unfortunately, although the rates of reaction will clearly be more rapid with increased temperature, it is not at all clear that the reaction products resulting from the high temperature interaction will resemble those expected to exist at a lower temperature. The potential dangers in making this assumption and the consequences that result from predicting waste form performance based on such accelerated tests have been noted by Jenkins et al. (1984). To determine if this method of accelerating tests is valid for waste package environment experiments pertinent to a potential repository at 
Yucca Mountain, we need to identify the run products and characterize their composition. The tuff/water interaction experiments run using solid core wafers in the Dickson-type gold-bag rocking autoclaves (Knauss and Beiriger, 1984b; Knause et al., 1985a and b) will aid in providing this information.

\section{Acknowledgments}

Thanks to Bob Rosenbauer (USGS-Menlo Park) and Bill Seyfreid (University of Minnesota) for much valuable advice on avoiding pitfalls in setting up the Dickson-type autoclaves. Thanks also to Jay Alexander for nlumbing in the pressure lines to the racks and to Carl Boro for remachining pressure vessel parts. Art Langhorst and Winnie Burks made the ICP-ES measurements on the direct reading unit, and Terry Duewer made the measurements on the sequential unit. Jackie Lam made IC measurements. Bob Lim and Jeff Haas made AA measurements. ('uck Slettevold and Suzie Saunders made ine BET analyses. Gayle Pawloski made the quantitative XRD analyses. Thanks to all these analysts for their excellent work. 


\section{Bibliography}

Bish, D. L., F. A. Caporuscio, J. F. Copp?, B. M. Crowe, J. D. Purson, J. R. Smyth, and R. G. Warren (1981), Preliminary Stratigraphic and Petrologic Characterization of Core Samples from USW G-1, Yucca Mountain, Nevada, Los Alamos National Laboratory, Los Alamos, NM, LA-8840-MS.

Byers, F. M. (1984), Los Alamos National Laboratory, Los Alamos, NM, personal communication.

Delany, J. M. (1985), Reuction of Topopah Spring Tuff with J-J3 Water: A Geochentical Modeling Approach Using the EQ3/6 Reaction Path Code, Lawrence Livermore National Laboratory, Livermore, CA, UCRL-53631.

Dibble, W. E. and W. A. Tiller (1981), "Kinetic Model of Zeolite Paragenesis in Tuffaceous Sediments," Clays and Clay Miner 29, 323-330.

Fournier, R. O. and J. J. Rowe (1962), "The Solubility of Cristobalite along the Three-Phase Curve, Gas Plus Liquid Plus Cristobalite," Am. Mineral 47, 897-902.

Holdren, G. R., and R. A. Berner (1979), "Mechanism of Feldspar Weathering -I. Experimental Studies," Geochim. Cosmochim. Acta 43, 1161-1171.

Jenkins, D. M., J. R. Holloway, and J. F. Kacoyannakis (1984), "Temporal Variations of Aqueous Constituents in a Water-Basalt-Supercalcine System: Implications for the Experimental Assessment of Nuclear Waste Forms," Geochim. Cosmochin. Acta 48, 1443-1454.

Knauss, K. G. (1984), Petrologic and Geochemical Characterization of the Topopal Spring Member of the Paintbrush Tuff: Outcrop Samples Used in Waste Package Experiments, Lawrence Livermore National Laboratory, Livermore, CA, UCRL-53558.

Knauss, K. G., and W. J. Beiriger (1984a), Report on Static Hydrothermal Alteration Studies of Topopah Spring Tuff Wafers in J -13 Water at $150^{\circ} \mathrm{C}$, Lawrence Livermore National Laboratory, Livermore, CA, UCRL53576.

Knauss, K. G., and W. J. Beiriger (1984b), "Dachiardite Formation by Hydrothermal Alteration of a Devitrified High-Silica Rhyolite," Geol. Soc. Am. Progr. Abstr. 16(6), 561.

Knauss, K. G. J. D. Delany, W. J. Beiriger, and D. W. Peifer (1984), "Hydrothermal lnteraction of Topopah Spring Tuff with J-13 Water as a Function of Temperature, accepted for publication in Mat. Res. Soc. Symp. Proc.

Knauss, K. G., W. J. Beiriger, D. W. Peifer, and A. J. Piwinskii (1985a), Hydrothermal Interaction of Solid Wafers of Topopah Spring Tuff with J-13 Water and Distilled Water at $90^{\circ} \mathrm{C}, 150^{\circ} \mathrm{C}$, and $250^{\circ} \mathrm{C}$ Using the Dickson-Type Gold Bag Rocking Autoclaves: 1. Short-. " Experiments, Lawrence Livermore National Laboratory, Livermore, CA, UCRL-53645.

Ḱnauss, K. G., W. J. Beiriger, and D. W. Peifer (1985b), Hydrothermal Interaction of Solid Wafers of Topopah Spring Tuff with J-13 Water at $90^{\circ} \mathrm{C}$ and $150^{\circ} \mathrm{C}$ Using the Dickson-Type Gold Bag Rocking Autoclaves: 2. Long-Term Experiments, Lawrence Livermore National Laboratory, Livermore, CA, UCRL-53722.

Oversby, V. M. (1984a), Reaction of Topopah Spring Tuff with J-13 Well Water at $90^{\circ} \mathrm{C}$ and $150^{\circ} \mathrm{C}$, Lawrence Livermore National Laboratory, Livermore, CA, UCRL-53552.

Oversby, V. M. (1984b), Reaction of Topopah Spring Tuff with J-13 Well Water at $120^{\circ} \mathrm{C}$, Lawrence Livermore National Laboratory, Livermore, CA, UCRL-53574.

Oversby, V. M. (1985), Reaction of Topopah Spring Tuff from Drillcores USW G-1, USW GU-3, USW G-4, and $U E-2 j h \# 1$ with $\mathrm{J}-13$ Water at $150^{\circ} \mathrm{C}$, Lawrence Livermore National Laboratory, Livermore, CA, UCRL-53629.

Oversby, V. M., and K. G. Knauss (1983), Reaction of Bullfrog Tuff with J-13 Water at $90^{\circ} \mathrm{C}$ and $150^{\circ} \mathrm{C}$, Lawrence Livermore National Laboratory, Livermore, CA, UCRL-53442.

Pawloski, G. A. (1983), Quantitative Determination of Minerals in Nevada Test Site Samples by X-Ray Diffraction, Lawrence Livermore National Laboratory, Livermore, CA, UCRL-89414.

Petrovich, R. (1981), "Kinetics of Mechanically Comminuted Rock-Forming Oxides and Silicates -I. Deformation and Dissolution of Quartz Under Laboratory Conditions," Geochim. Cosmochim. Acta 45 16651674.

Seyfreid, W. E., P. C. Gordon, and F. W. Dickson (1979), "A New Reaction Cell for Hydrothermal Solution Equipment," Am. Miner. 64, 646-649.

Stein, W., J. N. Hockman, and W. C. O'Neal (1984), Thermal Analysis of NNWSI Conceptual Waste Package Designs, Lawrence Livermore National Laboratory, Livermore, CA, UCID-20091. 
Travis, B. J., S. W. Hodson, H. E. Nuttal, T. L. Cook, and R. S. Rundberg (1984), Preliminary Estimates of Water and Radionuclide Transport in Yicra Mountain, Los Alamos National Laboratory, Los Alamos, NM, LA-UR 84-40 (Rev.).

Tyler, L. D. (1982), memorandum from L. D. Tyler of SNL to D. Veith of WMPO, NNWSI, dated July 9, 1982.

Walther, J. V., and H. C. Helgeson (1977), "Calculation of the Thermodynamic Properties of Aqueous Silica and the Solubility of Quartz and its Polymorphs at High Temperatures and Pressures," Am. J. Sci $277,1315-1351$.

Walther, J. V., and P. M. Orville (1983), The Extraction-Quench Technique for Determination of the Thermodynamic Properties of Solute Complexes: Application to Quartz Solubility in Fluid Mixtures, Am. Mineral. 68, 731-741.

Warren, R. G., F. M. Byers, and F. A. Caporuscio (1984), Petrography and Mineral Chemistry of Units of the Topopah Spring, Calico Hills, and Crater Flat Tuffs, and Older Volcanic Units, with Emphasis on Samples fromt Drill Hole USW G-1, Yucca Mountain, Nevada Test Site, Los Alamos National Laboratory, Los Alamos, NM, LA-10003-MS. 